\title{
Health Impact of the Indiscriminate use of Herbicides in Nigeria
}

\author{
Article by Oche Joseph Otorkpa \\ Master of Public Health, Texila American University, Guyana \\ E-mail: ochejoseph@yahoo.com
}

\begin{abstract}
The health impact of the indiscriminate use of herbicides in Nigeria is a public health concern. randomly selected food crops were found to be contaminated with residues of herbicides such as 2, 4-dichlorophenoxyacetic acid $(2,4-D)$ at $0.59 \mathrm{mg} / \mathrm{kg}$ beyond maximum residue limits of $0.1 \mathrm{mg} / \mathrm{kg}$, while residues appear to persist in the soil at very high concentration of 0.180 and $0.023 \mathrm{mg} / \mathrm{kg}$ for atrazine and paraquat respectively, therefore increasing the risk of surface and ground water contamination with potentially lethal consequences on humans, livestock, and the environment. There is high prevalence of disregard for safety measures amongst horticultural farmers, (42\%) of them do not use any form of protective wear during application of herbicides. Despite the establishment of links between the most commonly used herbicides in the country and certain forms of cancer, the sales of herbicide is still controlled mainly by semi-literate traders in open markets which appears to be contributing significantly to the level of pollution in the country. Based on the weight of evidence analyzed, the haphazard nature of the agrochemicals market and the indiscriminate use of herbicides in Nigeria cannot be completely extricated from the increasing rate of cancer in the country.
\end{abstract}

Keywords: Herbicides, Indiscriminate, Contamination, Health, Impact

\section{Introduction}

Herbicides are substances, mainly chemicals used to destroy, slow down, inhibit, or control the growth of plants or vegetation. Some are selective which implies that they act only on certain types of plant while the non-selective ones have impact on any vegetation they come in contact with. Most times the impact of herbicides tend to be underestimated largely due to the wrong perception of the word "herb", and the wrong notion that herbicides hardly come in contact with our food. This is not so because the contamination of groundwater, soil, plants, and habitats has a huge impact not just on humans, but also on animals. A vast number of chemical agents found in the environment are known to be toxic to biological systems, especially in high concentrations. These substances found in the environment are usually as a result of industrial and agricultural activities. They sometimes occur naturally in the lithosphere. Human exposure to toxic materials carries a great risk of morbidity, and mortality ${ }^{[1]}$.

The vast majority of the Nigerian population are into agriculture, and this vocation accounts for a significant portion of the nation's gross domestic product (GDP). Over the years, as environmentalists continue to mount pressure on government, successive regimes have responded by initiating policies that deter bush burning, due to its attendant risk and negative impact on the environment. These measures have compelled many farmers and households to switch to herbicides and other chemicals as their principal means of clearing lands, and for the control of seasonal weeds and unwanted plants. With relatively little or no knowledge about the composition of the chemicals they purchase or the required ratio of water to herbicides, these users are transforming Nigerian farms and communities into enclaves saturated with toxic levels of dangerous chemicals especially organophosphates and organochlorides which has the potential of persisting in the environment for a long time, and impacting negatively on the wellbeing of the population. 
Texila International Journal of Public Health

Volume 5, Issue 1, Mar 2017

An ecological study of Kentucky counties linked water contamination, corn crop production, pesticide use, and triazine herbicides to breast cancer risk, suggesting an increased risk of breast cancer in relation to an increased level of triazine herbicide exposure. Herbicide toxicity may also be linked to birth defects. Defects were $60-90 \%$ more likely in counties where large amounts of wheat were grown, as well as in babies conceived in springtime when nearby wheat crop herbicide spraying was heaviest, (up to 5x more likely). Likewise, herbicides have been linked to female infertility. Reports indicate that mixing and applying herbicides 2 years before attempting conception was more common among infertile women, as was the use of fungicides. A trazine (the most commonly used herbicide), and other chemicals have also been shown to have an adverse effect on endocrine, immune, and nervous system function. This links herbicides to such things as Attention Deficit Disorder/Attention Deficit Hyperactivity Disorder (ADD/ADHD), among other disorders and illnesses. ${ }^{[2]}$ A large percentage of those who suffer from the haphazard use of these herbicides are children. Children also breathe faster and have faster heart rates than adults, making them more vulnerable to aerosolized biological and chemical agents. Children metabolize drugs differently, requiring different dosages of drugs and different antidotes to many agents, as well as specially sized equipment to administer many treatments ${ }^{[3]}$.

\section{Objective}

The objective of this research is to provide an overview of the health impact of the indiscriminate use of herbicides with a view to elicit a change in the current policy regarding the administration of herbicides and related products.

\section{Methodology}

Review of Literature and direct observation.

\section{Basic findings}

\section{Level of food contamination by herbicides}

Due to the wide spread use of herbicides in agricultural activities in Nigeria, several studies have evaluated the concentration of herbicide residue and other organic contaminant on crops. Based on a study conducted in Plateau State, North Central Nigeria, Gushit et al reported that root crops like potato, yam and cassava were observed to contain considerably high concentration of herbicide residues with their derivatives. The three samples studied consist of at least one or two of the residues of herbicides which include 2, 4-dichlorophenoxyacetic acid $0.02 \mathrm{mg} / \mathrm{kg}$, atrazine $-0.10 \mathrm{mg} / \mathrm{kg}$ and atrazine $-0.08 \mathrm{mg} / \mathrm{kg}$ respectively, being herbicide residues with relatively significant concentration. These substances were identified as residues of the herbicides which were widely used in these farms. The trend showed that benzene carboxylic acid and its derivatives detected in majority of the crops under review are most likely the derivatives of organic based chemicals, and other pesticides commonly used for farming activities within the area of study. Atrazine and 2,4-D derivatives present in the samples was high with an average concentration of 0.09 and $0.59 \mathrm{mg} / \mathrm{kg}$ respectively. The average concentration of 2, 4-D is below the maximum residue limit (MRL) of $0.10 \mathrm{mg} / \mathrm{kg}$ for edible offal's, and is above the MRL of $0.10 \mathrm{mg} / \mathrm{kg}$ for set rice husked, and polished rice. While the average concentration of atrazine was well below the MRL of $0.10 \mathrm{mg} / \mathrm{kg}$ stipulated for atrazine in maize, pineapple, sugar cane and sweet corn ${ }^{[7]}$.In addition PAN assessment the study (2007) revealed that containers of used pesticides and insecticides were being used by the local people to store consumable products like water, palm oil and vegetable oil. ${ }^{[20]}$ 
Texila International Journal of Public Health

Volume 5, Issue 1, Mar 2017

Table 1. Residue profile of selected crop samples

\begin{tabular}{|c|c|c|c|c|c|}
\hline $\begin{array}{c}\text { Sample } \\
\text { Code }\end{array}$ & Crop type & Residues available & $\mathrm{RT}(\mathrm{min})$ & $\%$ area & $\begin{array}{c}\text { Conc } \\
(\mathrm{mg} / \mathrm{kg})\end{array}$ \\
\hline SHD-g & G/Nut & $\begin{array}{c}\text { (E, E) 2, 4-Decadienal } \\
\text { 4,4-bypyridine } \\
\text { atrazine } \\
\text { n-hexadecanoic acid } \\
\text { pendimethalin } \\
\text { Oleic acid } \\
\text { Mono (2-ethylhexyl ester) 1,2-benzene } \\
\text { DCacid } \\
2,6,10,14,18,22 \text {-tetracosahexaene } \\
1 \text {-(methoxymethoxy) butylthiane }\end{array}$ & $\begin{array}{l}4.42 \\
11.43 \\
18.89 \\
24.74 \\
25.15 \\
27.17 \\
33.28 \\
38.76 \\
41.43\end{array}$ & $\begin{array}{c}1.84 \\
2.67 \\
5.15 \\
18.53 \\
3.29 \\
17.16 \\
12.62 \\
2.57 \\
2.75\end{array}$ & $\begin{array}{l}0.04 \\
0.03 \\
0.10 \\
0.37 \\
0.07 \\
0.34 \\
0.25 \\
0.05 \\
0.06\end{array}$ \\
\hline BKK-p & Potato & $\begin{array}{c}\text { 2,5-bis (1,1-dimethylethyl) phenol } \\
\text { 1-heptadecene } \\
\text { 2,4-diclorophenoxy acetyl } \\
\text { (E)-5-Octadecene } \\
\text { Buty-1,2-ethylhexyl ester 1,2-benzene DC } \\
\text { acid } \\
\text { Diis oocyl ester 1,2-benzene DC acid }\end{array}$ & $\begin{array}{l}12.28 \\
15.80 \\
19.20 \\
21.12 \\
23.63 \\
33.80\end{array}$ & $\begin{array}{l}3.49 \\
2.77 \\
0.94 \\
3.17 \\
2.18 \\
87.46\end{array}$ & $\begin{array}{l}0.07 \\
0.06 \\
0.02 \\
0.06 \\
0.04 \\
1.75\end{array}$ \\
\hline JJN-c & Cucumber & $\begin{array}{c}\text { Atrazine } \\
\text { buty-1-octyl ester, } 1,2 \text {-benzenedicarboxylic } \\
\text { acid } \\
\text { mono (2-ethylhexyl) ester, 1,2-BenzeneDC } \\
\quad \text { acid } \\
\text { 1,3,3-trimethyl-2-(1-methylbut-1-en-3-on- } \\
\text { 1-yl)-1 cyclohexene }\end{array}$ & $\begin{array}{l}19.06 \\
23.63 \\
33.84 \\
41.18\end{array}$ & $\begin{array}{c}7.03 \\
0.68 \\
37.60 \\
60.31\end{array}$ & $\begin{array}{l}0.14 \\
0.01 \\
0.75 \\
1.20\end{array}$ \\
\hline BSA-r & Rice straw & $\begin{array}{c}\text { 4,4-bypyridine } \\
\text { Atrazine } \\
\text { Oleic acid } \\
\text { benzenedicarboxylic acid ester } \\
\text { Octadecanoic acid }\end{array}$ & $\begin{array}{l}12.09 \\
18.90 \\
27.73 \\
33.76 \\
28.26\end{array}$ & $\begin{array}{c}33.62 \\
3.83 \\
0.83 \\
53.57 \\
4.21\end{array}$ & $\begin{array}{l}0.67 \\
0.07 \\
0.02 \\
1.07 \\
0.08\end{array}$ \\
\hline $\mathrm{SAD}-\mathrm{y}$ & Yam tuber & $\begin{array}{c}\text { 3,3-bis-tert butylsulfanyl-2-fluorocylonitrile } \\
\text { 3,5-bis (1,1-dimethyl) phenol }\end{array}$ & 15.63 & 1.82 & 0.36 \\
\hline QPN-c & Cassava tuber & $\begin{array}{c}\text { Atrazine } \\
\begin{array}{c}\text { Butyl cyclohexyl ester-1,2- } \\
\text { benzyldicarboxylic acid }\end{array}\end{array}$ & $\begin{array}{l}18.91 \\
33.58\end{array}$ & $\begin{array}{c}4.12 \\
23.00\end{array}$ & $\begin{array}{l}0.08 \\
0.40\end{array}$ \\
\hline BKK-a & Acha straw & $\begin{array}{c}\text { 1,2-benzyl dicarboxylic acid } \\
\text { 4,4-bypridine }\end{array}$ & $\begin{array}{l}33.67 \\
33.34 \\
\end{array}$ & $\begin{array}{l}53.07 \\
1.02 \\
\end{array}$ & $\begin{array}{l}1.06 \\
0.02\end{array}$ \\
\hline
\end{tabular}

Source: Gushit, J. S. (2013) Analysis of Herbicide Residues and Organic Priority Pollutants in Selected Root and Leafy Vegetable Crops in Plateau State, Nigeria

\section{Level of safety consciousness}

Due to the toxic nature of herbicides, there is the constant need to always put safety first in the handling, storage, and application of herbicides. However, the level of safety consciousness amongst Nigerian farmers is low, due to low literacy level in the country. Majority of users do not even know the content of the chemicals they purchase, how dangerous the substances could be, and the safety measures to be adopted while applying such chemicals. In his work, Assessing the safety use of herbicides by horticultural farmers in River state south Nigeria, Iyagba Reported that $58 \%$ of horticultural farmers used protective wears during the application of herbicides, representing just over half the population sampled. Furthermore, $51 \%$ discard left over spray mixture into rivers and seas, and 58\% kept talking during the application period. ${ }^{[8]}$. 
Texila International Journal of Public Health

Volume 5, Issue 1, Mar 2017

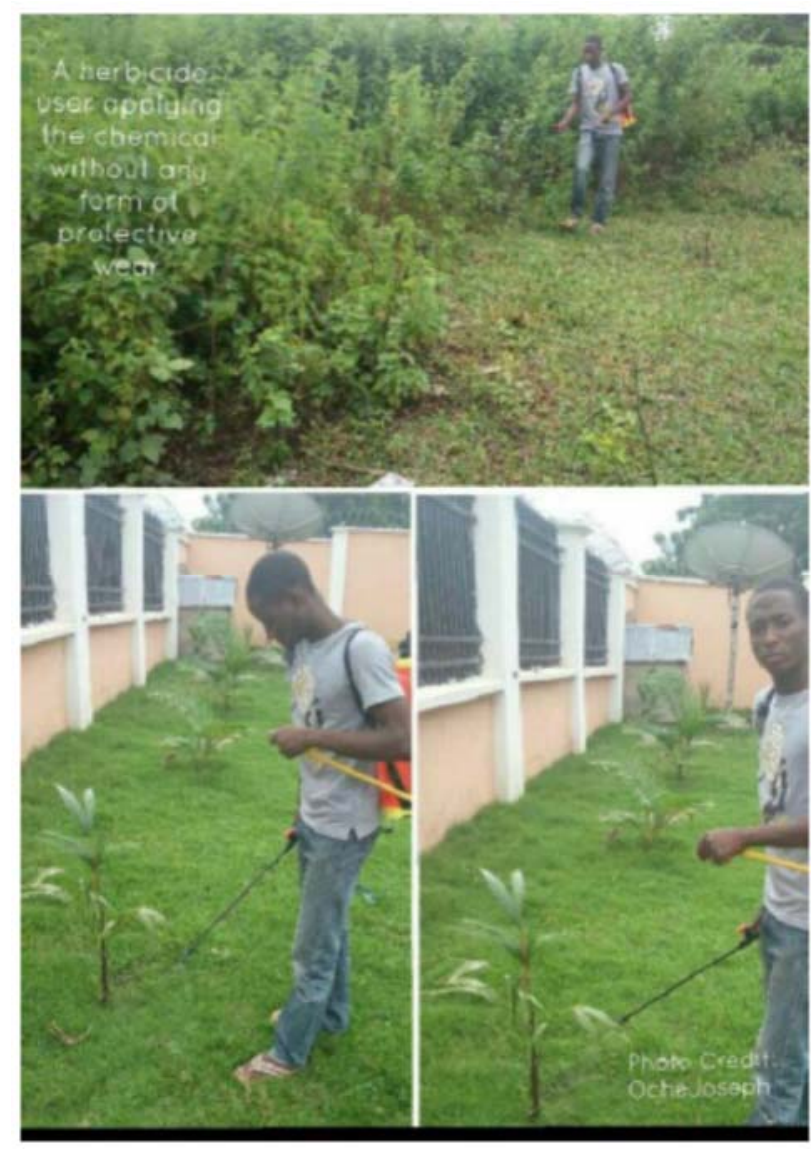

\section{Level of persistence in the soil}

Persistence of herbicides refers to the length of time herbicide remains active in the soil after application which is usually expressed in terms of half-life (abbreviated $t_{1 / 2}$ ), defined as the time required for a quantity to reduce to half its initial value. A lot of factors such as microbial population, $\mathrm{PH}$, soil texture, and structure influence the persistence of herbicide residue in the soil. In their work Persistence of herbicide residue in fadama and upland soil in Plateau State, Nigeria, Gushit et al reported that the average concentration in $\mathrm{mg} / \mathrm{kg}$ of the residues in the soils were as follows; atrazine $(0.123), 2,4-\mathrm{D}(0.013)$, paraquat $(0.020)$, oxadiazon $(0.100)$ and pendimethalin $(0.020)$ for fadama soils. While the concentration of the atrazine, 2, 4-D, paraquat, oxadiazon and pendimethalin in upland soils were $0.180,0.023$, $0.030,0.0130$ and $0.010 \mathrm{mg} / \mathrm{kg}$ respectively, suggesting that herbicide residues persist at considerably high concentration" ${ }^{10]}$.

\section{Herbicides and water sources}

One of the characteristics of herbicides is their ability to persist in the environment long after they have effected their weed killing function. Their persistence in the soil is a public health dilemma because of the potential of leaching into ground water and contaminating surface water either as a result of spills, erosion, run-off, or waste water discharges. Majority of Nigerians, especially rural dwellers still depend on stream, rivers, and lakes for their drinking water supply, about $51 \%$ of Nigeria's 165 million population resides in rural or remote areas and only $47 \%$ of this rural populace have access to improved water sources. Of the $49 \%$ that live in urban and peri-urban areas, only $72 \%$ of have access to improved water source ${ }^{[21]}$ The Nigerian standard for drinking water quality approved by the governing council of the Standards Organization of Nigeria in 2007 Stipulates the mandatory limits regarding constituents and contaminants of water that could be deleterious to human health. 
The document provided parameters for 2, 4, 6 - trichlorophenol at a maximum permitted level of $0.02 \mathrm{mg} / \mathrm{l}$ but providing no limits for majority of the most commonly used herbicides in Nigeria ${ }^{[12]}$.Water sources in Nigeria are highly exposed to contamination and pollution due to lack of stringent environmental laws. Iyagba in his study reported that $51 \%$ of horticultural farmers discarded left over spray mixture into rivers and seas ${ }^{[8]}$ while Ezemonye et al recorded concentrations of organochlorides, organophosphate, and carbamates in Warri River, Niger Delta, Nigeria ${ }^{[9]}$.

\section{Human health and herbicides}

There are many ways in which herbicides gain entry into the human body, access could either be via inhalation, through the oral route, or through the skin. The impact of human exposure to herbicides could be acute in which case there is a rapid onset and manifestation of symptoms of the poison, or chronic as a result of the long term exposure and accumulation of these substances in the body. The exposure of humans to herbicides have been linked to female infertility, miscarriages, birth defects, attention deficit disorder and increased risk of cancer .There is a wide spread exposure of Nigerians to herbicides especially during rainy season as a result of the use of herbicides for land preparation by famers, and elimination of weeds and unwanted vegetation by households. Many are oblivious of the potential consequences of these lethal substances as attested to by the report of the Strategic Assessment of the Status of POPs Pesticides Trading in South Western Nigeria, which indicated that there was an increasingly low knowledge level among members of the public including POP pesticide users, on the health risks associated with exposure to these substances going by the report of people storing consumable products like water, palm oil and vegetable oil in evacuated pesticide container ${ }^{[23]}$.The World Health Organization's International Agency for Research on Cancer (IARC) recently classified a widely used herbicide 2,4-dichlorophenoxyacetic acid otherwise known as 2,4,-D as a product that could "possibly" cause cancer in humans. The agency's reclassification of this herbicides followed a review of latest scientific literature which also led to the reclassification of another widely used herbicide glyphosate which the agency labelled as "probably carcinogenic to humans. ${ }^{[20]}$ This is consistent with the findings of Swanson et al who reported in their study that glyphosate disrupts the endocrine system and the balance of gut bacteria, it damages DNA and is a driver of mutations that lead to cancer. A conclusion arrived at after a correlation analyses returned a Pearson correlation coefficients that were highly significant $(<10-5)$ between glyphosate applications and a long list of diseases, illnesses, and conditions including cancer ${ }^{[22]}$.

\section{Regulations of herbicides}

The National Agency for Food Drug Administration and Control, (NAFDAC) is the body saddled with the responsibility of regulating the registration, import, production and administration of herbicides and other chemicals in Nigeria, while the Standards Organization of Nigeria (SON) is the agency that ensures standards. The registration of new products involves the submission of data relating to product composition, manufacturer, product risk to humans, and the environment as well as field trials to evaluate the efficacy of claims made. The Nigerian agrochemicals market is indiscriminately saturated with both registered and unregistered products and majority of users obtain these products from the open market. This is consistent with the findings of an earlier survey which reported that (55\%) of horticultural farmers obtained their herbicides from the open market ${ }^{[8] \text {. }}$

Open markets in Nigeria are largely unregulated, as such unregistered and banned substances easily find their way into the market. This is consistent with the findings of the Strategic Assessment of the Status of Persistent Organic Pollutants carried out by Pesticides Action Network (PAN) Nigeria, which reported that despite the ban on certain categories of Persistent Organic Pollutants (POPs), these substances are still common in the markets, 
Texila International Journal of Public Health

Volume 5, Issue 1, Mar 2017

utilized in various locations in the society, and are considered potential threats to the environment and health of the population" ${ }^{[23]}$.

A typical agrochemicals market in rural Nigeria.

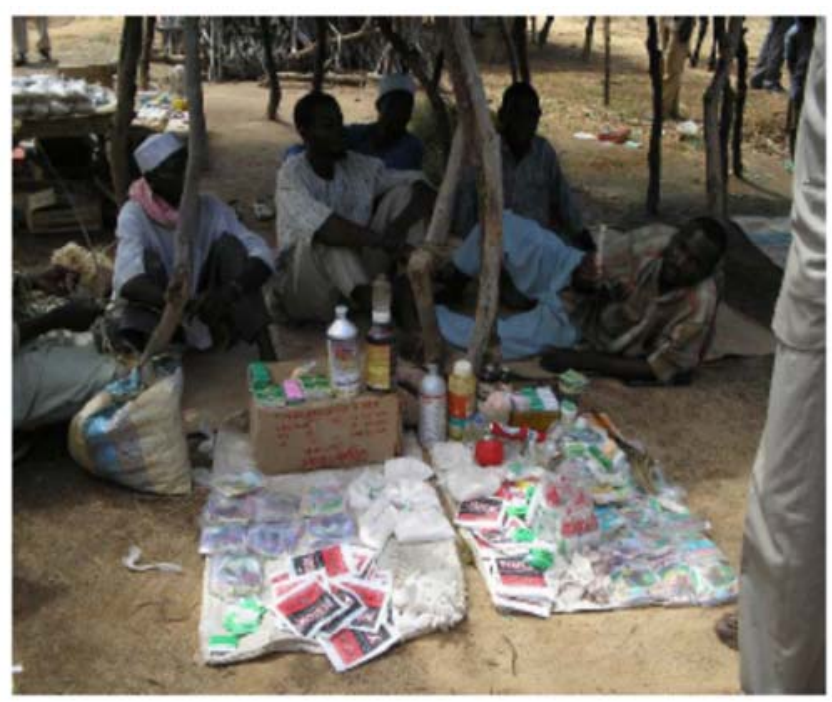

Photo Credit: VenuMargam

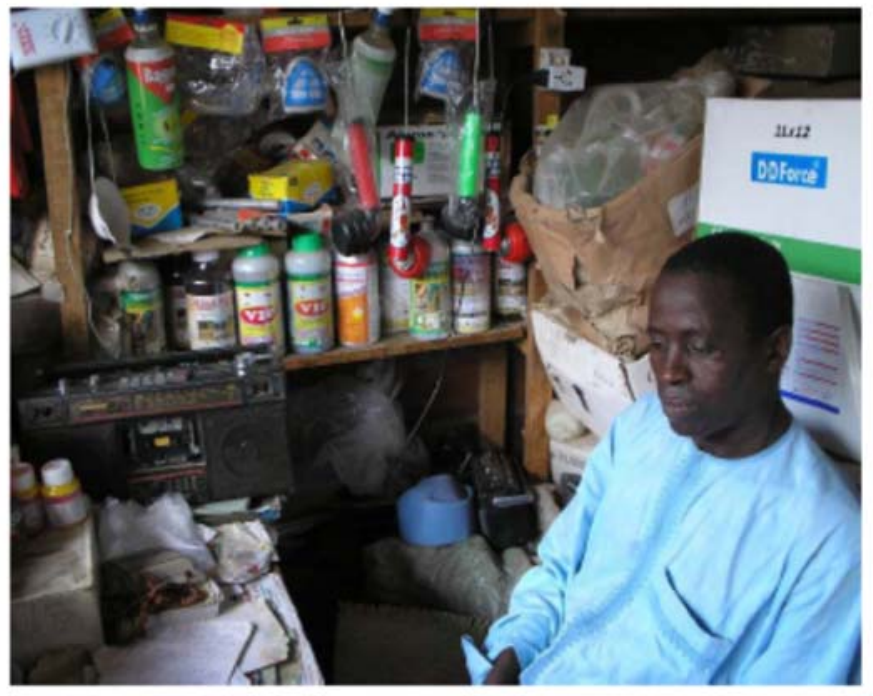

\section{Discussion}

As People seek for faster means of clearing farm lands, improving crop yield, and clearing vegetation, larger quantities of herbicides will be used, and more herbicide residues will find their way into our food. The presence of 2,4-dichlorophenoxyacetic acid otherwise known as 2,4,-D derivatives at a concentration of $0.02 \mathrm{mg} / \mathrm{kg}$, ${ }^{[7]}$ beyond the maximum residue limit (MRL) of $0.10 \mathrm{mg} / \mathrm{kg}$ set for edible offal's ${ }^{[7]}$ is a public health concern because of the recent finding that labelled the herbicide as a possible cause of cancer. The high level of noncompliance with recommended safety regulations as regards the handling of herbicides is also worrisome, owing to the fact that almost half, $(42 \%)^{[8]}$ of herbicide users do not comply with the use of protective wears during herbicide application. This could affect the potential of the country to feed itself when the long term impact of the direct exposure of farmers to herbicides weighs in .Another health impact of the indiscriminate use herbicides could come from water sources. The constant dumping of mixed herbicides into water bodies in Nigeria, 
especially rivers and seas as practiced by $51 \%$ of horticultural farmers surveyed by Iyagba ${ }^{[8]}$ is dangerous, especially when those water bodies also serve as a source of drinking water or fishing. The haphazard nature of the Nigerian agrochemicals market remains one of the major contributing factor to pollution and contamination of the environment. The post registration product neglect by NAFDAC and SON and their apparent non regulation of sales as required, rendered the Nigerian population vulnerable to a greater risk of exposure to these carcinogens. Available data, (2001-2005) from Ibadan showed increasing incidence and the Age-standardized rate (ASR) for all cancers as 81.6 per 100,000 for males, and 115.1 per 100,000 for females with $65.9 \%$ and $34.1 \%$ in females and males respectively. ${ }^{[25]}$ In addition, Cancer incidence data from two population based cancer registries in Nigeria suggests substantial increase in incidence of breast cancer in recent times. ${ }^{[24]}$ Herbicides and their residues which are prevalent in food and water sources in Nigeria cannot be completely extricated as a possible or associated cause of these conditions.

\section{Conclusion}

The impact of the indiscriminate use of herbicides in Nigeria has far reaching consequences beyond the location of where the herbicide was sprayed. Although some of these effects may not be immediate, most times the consequences are irreversible. Considering the level of exposure to herbicides in Nigeria due to lack of awareness, illiteracy, non-regulation, and the haphazard nature of the agrochemicals market, herbicides cannot the completely extricated from the increasing rate of cancer in the country, as such further research is recommended. Furthermore, there is an urgent need for government and other key players in policy making process to review the current nature of the agrochemicals market, especially herbicides in order to prevent an impending health crisis in the country.

\section{References}

[1]. Nnodimele, O.A. (2016). Module 6 Exposure to Environmental Hazardous Materials. In Nnodimele, O.A (Ed), Environmental Health (pp. 1-7). Guyana: Texila American University.

[2]. Nnodimele, O.A. (2016). Module 7 Environmental Toxicology. In Nnodimele, O.A (Ed), Environmental Health (pp. 1-7). Guyana: Texila American University.

[3]. Wikipedia.(2015).Wikipedia.org. Retrieved $11 \quad$ August, 2016, from https://en.wikipedia.org/wiki/Herbicide

[4]. North Central Weed Science Society. (2006). Ncwss.org. Retrieved 11 August, 2016, from http://ncwss.org/proceed/2006/abstracts/94.pdf

[5]. Herbicide resistance action committee (HRAC) group - o Weed Science Society of America (WSSA) group - 4. (2004). Agron. Retrieved 23 August, 2016, from http://agronwww.agron.iastate.edu/Courses/Agron317/Synthetic_auxins.htm

[6]. Sustainablebabysteps.com (N.P.). Sustainable baby steps. Retrieved 30 August, 2016, from http://www.sustainablebabysteps.com/herbicide-toxicity.html

[7]. Gushit, J. S. (2013). Analysis of Herbicide Residues and Organic Priority Pollutants in Selected Root and Leafy Vegetable Crops in Plateau State, Nigeria. World Journal of Analytical Chemistry, $1(2), 23-28$.

[8]. Iyagba A.G. (2010). Assessing the Safety Use of Herbicides by Horticultural Farmers in Rivers State. Nigeria. European Scientific Journal 9(15), 1-12

[9]. Ezemonye, L Ikpesu, T. O., Isioma, I. (2010), Distribution of endosulfan in water, sediment and fish from Warri River, Nigeria. Africa journal of Ecology; 48 (1), 248-254

[10]. John. S. Gushit, Eno. O. Ekanem, Harami. M. Adamu and Ovi. J. Abayeh (2012). The Persistence of Herbicide Residues in Fadama and Upland Soils in Plateau State, Nigeria. Journal of Environment and Earth Science, 2(10), 148-149.

[11]. Akinloye, O. A., Adamson, I., Ademuyiwa, O. \& Arowolo, T. (20110). Occurrence of paraquat residues in some Nigerian crops, vegetables and fruits. Journal of Environmental Chemistry and Ecotoxicology, 3(7), 195-198. 
Texila International Journal of Public Health

Volume 5, Issue 1, Mar 2017

[12]. Standards Organization of Nigeria. (2007). Uniceforg. Retrieved 30 August, 2016, from http://www.unicef.org/nigeria/ng_publications_Nigerian_Standard_for_Drinking_Water_Quality.pdf

[13]. Wilson C, Tisdell C (2001). Why farmers continue to use pesticides despite environmental, health and sustainability costs. Ecol. Econ.39, 449 - 462,doi: 10.1016/S0921-8009(01)00238-5

[14]. Vasilescu, M.N. Medvedovici, A.V.(2005). Herbicides. Encyclopedia of Analytical Science. 2nd ed. Elsevier, Oxford, 243-260, 2005. http://dx.doi.org/10.1016/ B0-12-369397-7/00256-9

[15]. Akpomie, T. M., Ekanem, E. O., \& Akpomie, J. O. (2016) Estimating the Degradation Half-life of Herbicides in the Soil Using Computer-developed Models. World Journal of Analytical Chemistry, 4. (2), 17-18.

[16]. Ayansina ADV, Oso, BA. (2006). Effect of two commonly used Herbicides on soil micro flora at two different concentrations. African Journal of Biotechnology, 5(2) 129 - 132.

[17]. Rolando, C. A., Garrett, L. G., Baillie, B. R., \& Watt, M. S. (2013). A survey of herbicide use and a review of environmental fate in New Zealand planted forests. New Zealand Journal of Forestry Science, $43: 7$.

[18]. Galadima, A., Garba, Z. N., Leke, L., Almustapha, M. N. \& Adam, I. K.(2011). Domestic Water Pollution among Local Communities in Nigeria ---- Causes and Consequences. European Journal of Scientific Research, 52(4), 92-603

[19]. Ibrahim MA, Bond GG, Burke TA, Cole P, Dost FN, \& Enterline PE.(1991) Weight of evidence on the human carcinogenicity of 2,4-D. Environ Health Perspect. 96, 213-22.

[20]. Reuters. (23 June 2015). The guardian. Retrieved 30 August, 2016, from https:/www.theguardian.com/environment/2015/jun/23/herbicide-24-d-possibly-causes-cancer-worldhealth-organisation-study-finds

[21]. Akali, D. M., O. T. Iorhemen, Otun J. A., and Alfa M. I. (2014). Provision of Sustainable Water Supply System in Nigeria: A Case Study of Wannune-Benue State. World Journal of Environmental Engineering 2, (1) 1-5.

[22]. Swanson NL, Leu A, Abrahamson J, Wallet B (2014). Genetically engineered crops, glyphosate and the deterioration of health in the United States of America. Journal of Organic Systems 9.

[23]. Pesticides action network (pan) nigeria. (2007). Pan-ukorg. Retrieved 1 September, 2016, from http:/www.pan-uk.org/archive/Projects/Obsolete/MDTF\%2008-

09/Nigeria\%20Trading\%20Case\%20study.pdf

[24]. Jedy-Agba E, Curado MP, Ogunbiyi O, Oga E, Fabowale T, Igbinoba F, Osubor G, Otu T, \& Kumai H, Koechlin A: Cancer incidence in Nigeria: A report from population-based cancer registries. Cancer Epidemiology,36 (5).

[25]. Fatimah Abdulkareem (2009); Epidemiology and Incidence of Common Cancers in Nigeria; Cancer Reg \& Epid Workshop April '09

[26]. Margam, V. (n.p.). entmpurdueedu. Retrieved 1 September, 2016, from https://www.entm.purdue.edu/NGICA/ejournal/pub01.html 